\title{
Influences of season, parity, lactation, udder area, milk yield, and clinical symptoms on intramammary infection in dairy cows
}

\author{
Z. Zhang, X. P. Li, F. Yang, J. Y. Luo, X. R. Wang, L. H. Liu, and H. S. Li ${ }^{1}$ \\ Key Lab of New Animal Drug Project, Key Laboratory of Veterinary Pharmaceutical Development, Ministry of Agriculture, \\ Lanzhou Institute of Husbandry and Pharmaceutical Sciences of Chinese Academy of Agricultural Science, Lanzhou 730050, China
}

\begin{abstract}
The aim of this study was to evaluate the influences of season, parity, lactation, udder area, milk yield, and clinical symptoms on bacterial intramammary infection (IMI) in dairy cows. A total of 2,106 mastitis pathogens in 12 species were isolated from 125 dairy farms distributed in 30 different cities in China, and the information about these factors was recorded at the same time. Mastitis pathogens were isolated from $63.43 \%$ of the milk samples, whereas Streptococcus agalactiae accounted for $38.61 \%$ of all pathogens, followed by Str. dysgalactiae (28.16\%), Staphylococcus aureus (19.10\%), Escherichia coli (6.90\%), and other pathogens (7.23\%). According to our investigation, IMI was more common in spring with the isolation rate of pathogens at $81.04 \%$, and lowest in winter $(52.34 \%)$. Cows were more likely to be infected by environmental pathogens $(E$. coli or Str. uberis) in summer, in rear quarters and in cows with higher daily milk yield or lower somatic cell count. In addition, Str. dysgalactiae exhibited a higher prevalence with increased parity. Different clinical symptoms of quarters with bacterial IMI were seen in this study, and mastitis pathogens were isolated from healthy quarters.
\end{abstract}

Key words: intramammary infection, pathogen, relationship, bovine mastitis

\section{INTRODUCTION}

Dairy cow mastitis is a serious disease associated with both high incidence (van den Borne et al., 2010) and economic losses (Holland et al., 2015), posing a major challenge to the dairy industry (Boboš et al., 2013; Leelahapongsathon et al., 2014). There are approximately 220 million dairy cattle worldwide. The incidence of clinical mastitis (CM) is estimated to

Received January 22, 2016.

Accepted April 25, 2016.

${ }^{1}$ Corresponding author: lihsheng@sina.com range between 16 and 48 cases per 100 cows (Kvapilik et al., 2014), and the prevalence of subclinical mastitis (SCM) is reported to be 20 to $80 \%$ globally (Kivaria, 2006; Contreras and Rodríguez, 2011). Research has demonstrated a wide range in the cost of mastitis, ranging from $\$ 16.43$ to $\$ 572.19$ per cow (Holland et al., 2015). Beside the financial implications of mastitis, the importance of mastitis with respect to public health should not be overlooked (Bradley, 2002). Milk from cows with mastitis accidentally mixed into bulk milk enters the food chain and has the potential to transmit pathogenic organisms and antibiotic residues to humans (Hameed et al., 2007). In addition, the extensive use of antibiotics to both prevent and treat mastitis likely contributes to the rise in antimicrobial resistance in the management of human infectious diseases (Leblanc et al., 2006).

Mastitis is complex, developing as a result of the interaction between various factors associated with the host, specific pathogens, environment, and management (Demme and Abegaz, 2015; Rashad et al., 2016). Over 200 different organisms have been recorded to cause bovine mastitis (Blowey and Edmondson, 2010). However, IMI is mostly caused by a much smaller range of pathogens. A better understanding of the prevalence and distribution of the major mastitis pathogens is important for the dairy industry to help guide specific control measures (Piessens et al., 2011).

According to the data from National Bureau of Statistics of the People's Republic of China, approximately 15 million dairy cattle are present in China ( $\mathrm{Li}$ et al., 2015). The incidence of mastitis was estimated to range between 16 and 75 cases per 100 cows. Annual losses associated with bovine mastitis were estimated to be 15 to 45 billion yuan, accounting for $38 \%$ of total direct costs related to dairy cattle health (Song and Yang, 2010; Memon, 2013). Although a great deal of research has been performed concerning various aspects of bovine mastitis in China, studies on the correlation between IMI and factors such as season, parity, lactation, and so on have not been reported. This study aimed to elucidate the prevalence of mastitis pathogens, identify the 
relationship between IMI and these factors and SCC, test for pathogens in samples from healthy cows, and provide information that can be used in bovine mastitis control programs.

\section{MATERIALS AND METHODS}

\section{Herds and Cows}

Data from 125 dairy farms distributed in 30 different cities in China were included in this study (Figure 1). The cows were primarily major China Holstein (hybrid of Holstein and Yellow cattle), and were housed in either a free stall or a tie stall with straw, sawdust, or something others as bedding. Most farms used the bucket-type milking machines for milking cows twice daily and postmilking teat disinfection and selective dry cow therapy based on udder health status. The mean herd size of the study herds was 553 cows, with an average production of $5,862 \mathrm{~kg}$ of milk/cow per year.

\section{Sampling and Processing}

Before sampling, the first streams of milk were discarded, and teat ends were disinfected with cotton swabs soaked in $75 \%$ alcohol and allowed to dry. A total of 3,134 milk samples were collected from 3,072 dairy cattle and samples $(\mathrm{n}=2,493)$ without evidence of CM were performed by Lanzhou Mastitis Test (LMT; scored at,,,- \pm+++ , and +++ , corresponding to negative, suspicious, weak positive, positive, and strong positive, respectively; Liu et al., 1983). The LMT is a diagnostic method of SCM, which is similar to the California Mastitis Test.

Samples of CM $(\mathrm{n}=641)$, SCM $(\mathrm{n}=1,808$, LMT score at,+++ , or +++$)$, and healthy cows $(\mathrm{n}=685$, LMT score at - or \pm ) were placed on ice and transported to the laboratory within $6 \mathrm{~h}$ of collection for bacteriological studies. Information regarding season, parity, lactation, udder area, milk yield, and clinical symptoms were recorded at the same time. Not all samples contain information as mentioned above because

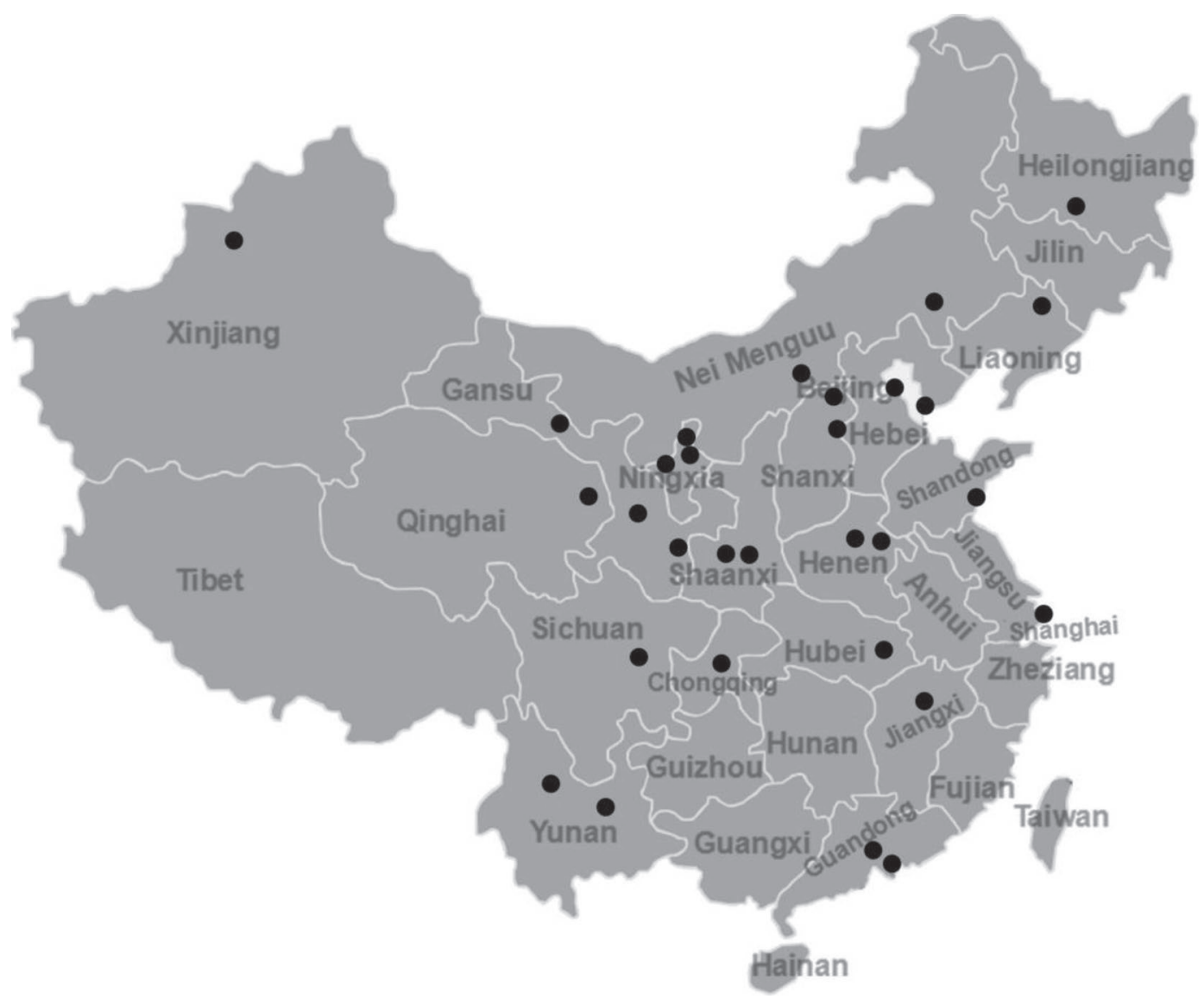

Figure 1. Distribution of cities in China involved in this study. 
no information was recorded in some small farms and the information on some samples collected by farmers and their veterinary surgeons was not recorded.

\section{Bacterial Identification}

Culturing and identification of the microorganisms to species level was carried out according to standard procedures described by Yuan et al. (1991) within $24 \mathrm{~h}$ after sampling. Briefly, a bacteriological loop was used to spread approximately 0.01 to $0.02 \mathrm{~mL}$ of each milk sample on blood agar, Chapman agar, Edward agar, MacConkey agar, and nutrient broth. The plates were incubated at $37^{\circ} \mathrm{C}$ and examined after $24 \mathrm{~h}$. Suspected colonies were purified and transferred to nutrient broth and agar slant culture medium. When slow-growing or unusual bacteria were suspected, longer incubation periods or on incubator environment of $10 \% \mathrm{CO}_{2}$ were used. If no growth occurred within $7 \mathrm{~d}$, samples were considered negative.

All isolates were identified based on colony appearance, conventional Gram staining, Christie, Atkins, Munch-Petersen (CAMP) reaction, and other biochemical methods as described by Yuan et al. (1991). The API Test (BioMérieux SA, Marcy l'Etoile, France) was also used if necessary.

\section{Statistical Analysis}

First, databases containing the results of bacterial identification and factors (season, parity, lactation, udder area, milk yield, and clinical symptoms) were built in a Microsoft Excel (Microsoft Corp., Redmond, WA) worksheet for analysis. These data were then used to estimate isolation rate of bacterium/pathogens on quarters level (number of bacterium/pathogens/IMI cases per 100 quarters) and distribution of pathogens (the proportion of specific pathogen in the total pathogens in each group). Second, chi-square analysis, as applied in the SPSS software version 22.0 (SPSS Inc., Chicago, IL), was used to assess the association between IMI and all above-mentioned factors. Statistical significance in this step was assessed at $P<0.05$.

\section{RESULTS}

\section{Distribution of Mastitis Pathogens}

Out of 3,134 milk samples collected and processed, $86.85 \%$ ( $\mathrm{n}=2,722$ ) were culture positive for bacteria. A total of 3,410 bacterial isolates of 24 species were obtained, and 2,106 isolates (63.43\%) of 12 species were identified as mastitis pathogens. Streptococcus agalac- tiae $(38.61 \%)$, Str. dysgalactiae $(28.16 \%)$, Staphylococcus aureus (19.10\%), and Escherichia coli (6.90\%) were the predominant isolates, accounting for $92.77 \%$ of all mastitis pathogens $(\mathrm{n}=2,106)$, and most of them were contagious bacteria $(85.87 \%)$.

\section{Relationships Between Mastitis Pathogens and Seasons}

As shown in Table 1, IMI was more common $(P<$ $0.01)$ in spring with the isolation rate of pathogens at $81.04 \%$, and lowest in winter $(52.34 \%)$. However, the isolation rate of $S$. aureus was highest in winter $(41.07 \%)$ and lowest in spring (16.23\%). A higher isolation rate of environmental pathogens (E. coli and Str. uberis) pathogens was seen in summer compared with other seasons $(P<0.05)$. However, the isolation rate of Str. agalactiae was significantly lower in summer compared with other seasons $(P<0.05)$.

\section{Relationships Between Mastitis Pathogens and Parity of Cows}

The data demonstrated in Table 2 revealed that mastitis pathogens were isolated with approximately equal frequencies between parities, and the distribution was similar to the general trend, of which Str. agalactiae was the dominant pathogen, followed by Str. dysgalactiae, S. aureus, and other pathogens. However, the isolation rate of Str. agalactiae increased gradually with increasing parity.

\section{Relationships Between Mastitis Pathogens and Lactation}

Among 2,493 milk samples from lactating cows, 1,650 $(66.19 \%)$ were collected in the early lactation period (1-300 d in milk) and the rest were from the late lactation period (7-10 d before dry period). As recorded in Table 3, the distribution of mastitis pathogens was similar to the general trend. However, the isolation rate of pathogens was higher $(P<0.01)$ in the early lactation stage $(60.18 \%)$ than the late lactation stage (50.95\%).

\section{Relationships Between Mastitis Pathogens and LMT}

As shown in Table 3, high LMT score was positively correlated with IMI. However, in late lactation, $S$. aureus and E. coli IMI was negatively correlated with LMT score. Furthermore, 241 mastitis pathogens were isolated from LMT negative samples $(\mathrm{n}=574)$. 
Table 1. Relationships between pathogenic species and season

\begin{tabular}{|c|c|c|c|c|c|c|c|c|c|c|c|c|c|c|}
\hline \multirow[b]{2}{*}{ Season } & \multirow[b]{2}{*}{$\begin{array}{c}\text { No. of } \\
\text { samples }\end{array}$} & \multirow{2}{*}{$\begin{array}{c}\text { Isolation } \\
\text { rate of } \\
\text { pathogens } \\
(\%)\end{array}$} & \multicolumn{12}{|c|}{ Distribution of pathogens ${ }^{1}(\%)$} \\
\hline & & & $\begin{array}{c}\text { S. } \\
\text { agal. }\end{array}$ & $\begin{array}{l}\text { S. } \\
\text { dys. }\end{array}$ & $\begin{array}{c}S . \\
\text { aur. }\end{array}$ & $\begin{array}{l}E \text {. } \\
\text { coli }\end{array}$ & $\begin{array}{c}\text { S. } \\
\text { uber. }\end{array}$ & Prot. & Kleb. & $\begin{array}{c}P . \\
\text { aer. }\end{array}$ & $\begin{array}{l}N . \\
\text { ast. }\end{array}$ & $\begin{array}{c}\text { S. } \\
\text { pyo.s }\end{array}$ & $\begin{array}{c}\text { C. } \\
\text { pyo. }\end{array}$ & $\begin{array}{c}C . \\
\text { alb. }\end{array}$ \\
\hline Spring & 571 & 81.04 & 55.85 & 17.18 & 16.23 & 6.92 & 2.39 & 0.72 & 0.95 & 0.95 & 1.43 & & & \\
\hline Summer & 716 & 59.50 & 23.47 & 28.17 & 21.36 & 15.73 & 3.05 & 0.47 & 0.70 & 2.11 & 3.17 & 0.70 & 0.70 & 0.23 \\
\hline Fall & 392 & 77.04 & 40.73 & 28.48 & 23.84 & 5.96 & 1.99 & & 1.99 & 1.32 & 1.32 & & & \\
\hline Winter & 107 & 52.34 & 28.57 & 17.86 & 41.07 & 7.14 & & & & & 1.79 & & & \\
\hline Total & 1,786 & 69.76 & 41.41 & 23.11 & 20.39 & 9.47 & 2.3 & 0.08 & 0.10 & 1.36 & 1.20 & 0.24 & 0.24 & 0.08 \\
\hline
\end{tabular}

${ }^{1}$ S. agal. $=$ Streptococcus agalactiae $;$ S. dys. = Streptococcus dysgalactiae $;$ S. aur. $=$ Staphylococcus aureus $;$ E. coli $=$ Escherichia coli $;.$ uber. $=$ Streptococcus uberis $;$ Prot. $=$ Proteus $;$ Kleb. = Klebsiella; P. aer. = Pseudomonas aeruginosa; N. ast. = Nocardia asteroides; S. pyo. = Streptococcus pyogenes; C. pyo. $=$ Corynebacterium pyogenes; C. alb. = Candida albicans.

Table 2. Relationships between pathogenic species and parity

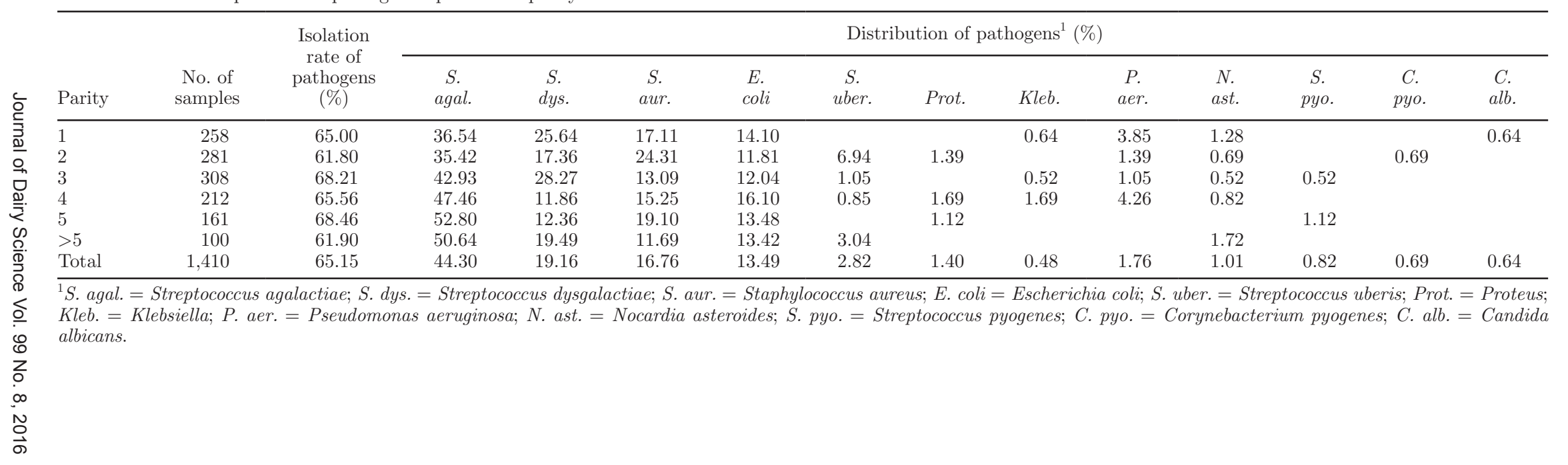




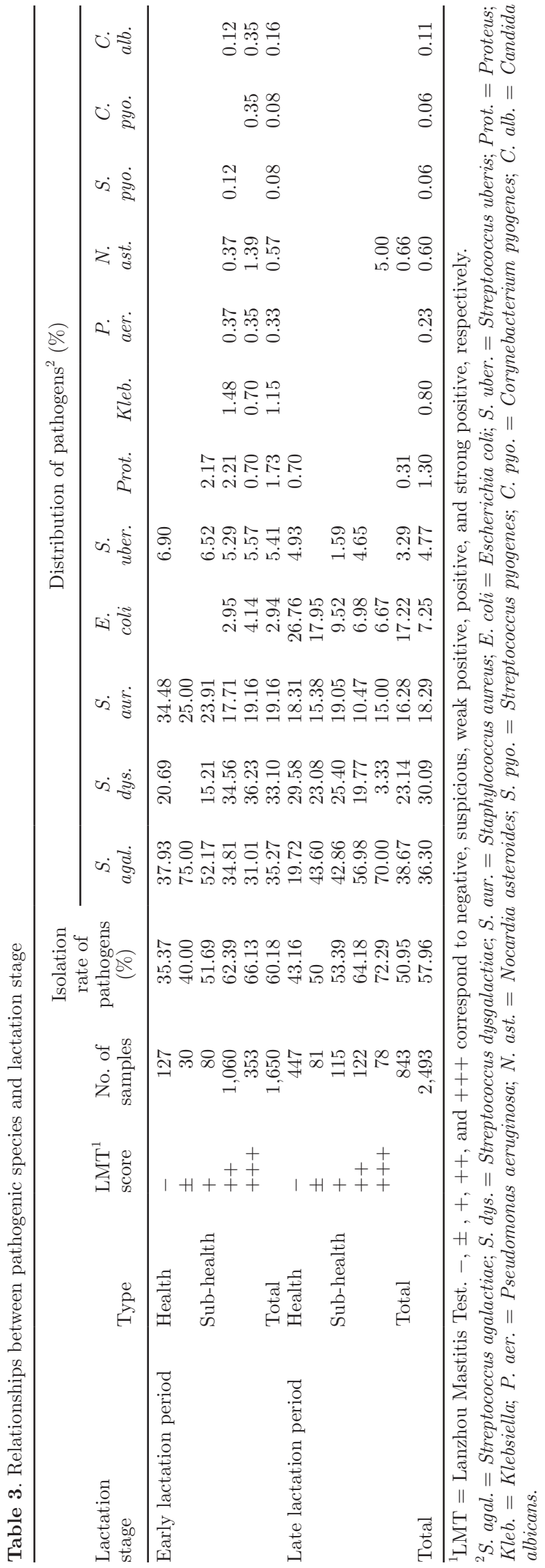

\section{Relationships Between Mastitis Pathogens and Udder Area}

As shown in Table 4, a nonsignificant association was found between different udder areas. The distribution of pathogens was similar to the general trend, but the level of IMI of front quarters was lower than posterior quarters. However, E. coli IMI was more common in posterior quarters $(P<0.01)$, and Str. agalactiae IMI was more common in front quarters $(P=0.05)$.

\section{Relationships Between Mastitis Pathogens and Milk Yield}

From the results presented in Table 5, the isolation rate of pathogens increased with the increasing daily milk yield (DMY) except for cows producing $<30 \mathrm{~kg}$ per $\mathrm{d}$ (this might be due in part to only 14 samples in this group) indicated that increased DMY was a risk for IMI $(P>0.05)$. However, cows with higher DMY tend to have a lower LMT positive rate. The IMI level of E. coli and Str. uberis was higher in cows with high $\operatorname{DMY}(P<0.01)$.

\section{Relationships Between Mastitis Pathogens and Clinical Symptoms of Udder}

As shown in Table 6, clinical symptoms (including redness, swelling, increased heat, and pain) of the udder can be caused by most pathogens, but the features vary depending on the type of bacteria. For example, udder will become larger and harder if it was infected with either Pseudomonas aeruginosa or $S$. aureus $(P$ $<0.01)$. Fever caused by $E$. coli IMI was significantly lower than other pathogens $(P<0.01)$. Redness and swelling induced by Str. agalactiae IMI was significantly lower than others $(P<0.01)$. Bloody milk (bleeding inside the udder) caused by Str. agalactiae IMI and nonbacteria (possibly virus, mycoplasma, mechanical damage, and so on) was significantly higher than other pathogens $(P<0.05)$.

\section{DISCUSSION}

A database containing information about bacteriological findings and factors recorded on individual cow based on our study was established. The results showed that contagious agent (Str. agalactiae, Str. dysgalactiae, and S. aureus) accounted for $85.87 \%$ of all IMI. This is in agreement with previous studies (Olde Riekerink et al., 2007a; Abdel-Rady and Sayed, 2009; Demme and Abegaz, 2015) and may be because these organisms can be spread easily from infected quarters to healthy ones through contaminated milkers' hands, cloth towels, or 

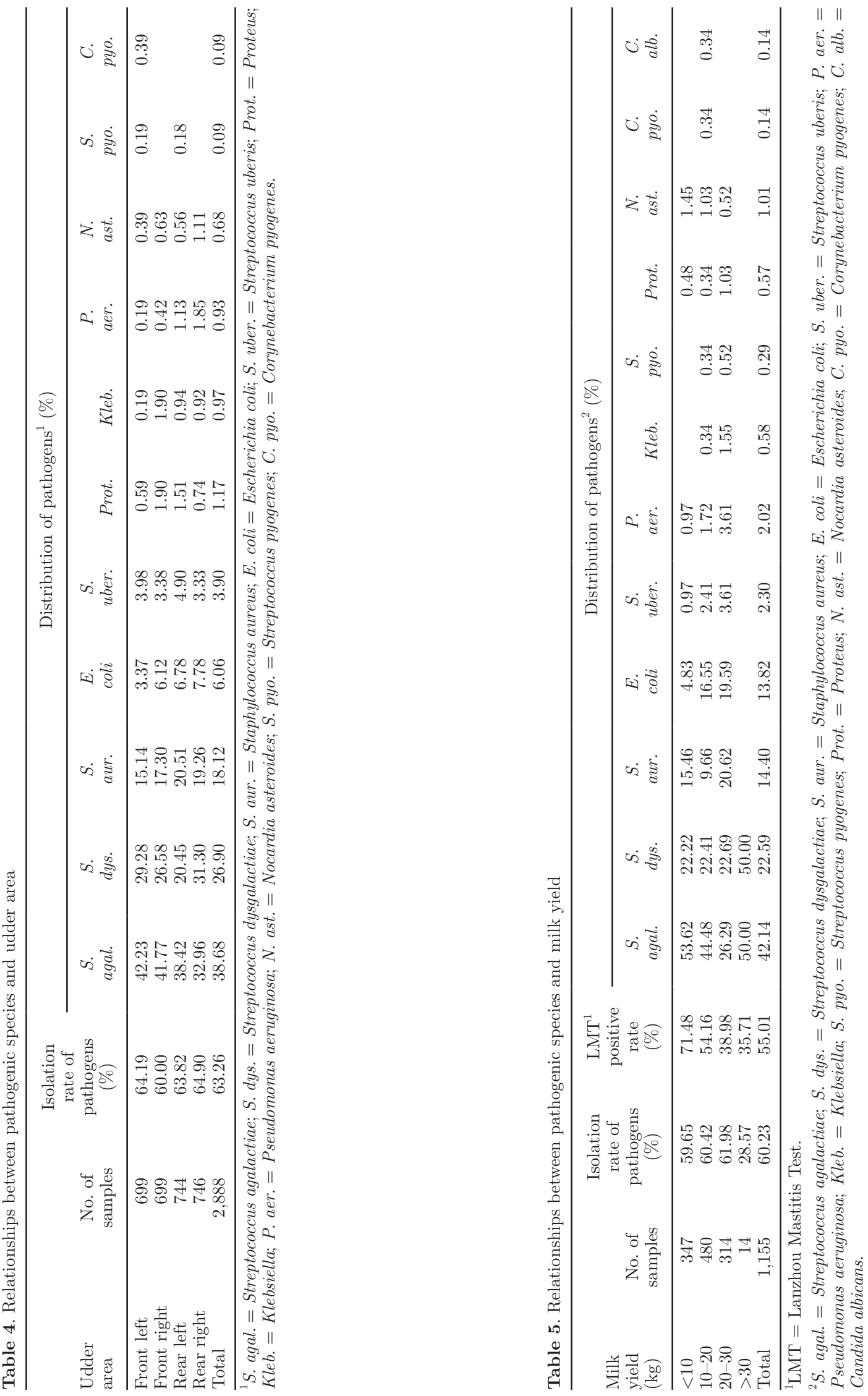


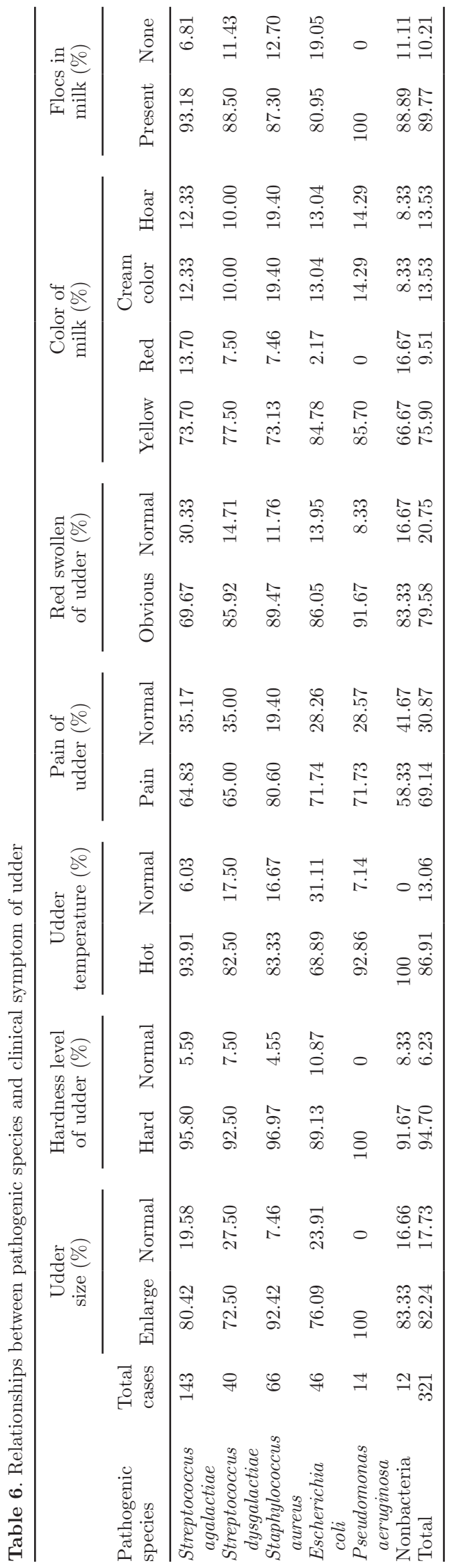

milking equipment (Fox and Gay, 1993). Rapid changes in dairy industry (from management style to mastitis control measures) have occurred during last few years, which may induce hard conditions for environmental pathogens (Zadoks and Fitzpatrick, 2009). A study carried out in Estonia found that contagious pathogens were more frequently in SCM (Kalmus et al., 2011), and only 641 samples were collected from CM compared with 1,808 from SCM in our study.

Streptococcus agalactiae, also known as group B Streptococcus, is one of the leading causes of bovine mastitis and an important human pathogen (Keefe, 1997). With increased use of udder health technologies and mastitis control programs, the prevalence of Str. agalactiae IMI has decreased during the last few decades. In Denmark, for example, Str. agalactiae IMI was reported to decrease from $40 \%$ in 1950 to about 2\% in 1992 (Mweu et al., 2012). In Massachusetts, an intraherd prevalence of $44.7 \%$ was found between 1976 and 1982, and only $10 \%$ of samples was positive for Str. agalactiae in 1992 (Keefe, 1997). In Ragusa, Str. agalactiae was isolated in fewer than $2 \%$ of 18,711 milk samples (Ferguson et al., 2007). In China, Str. agalactiae was still a major pathogen of bovine mastitis (Xu et al., 2005). However, in some other reports in China, the isolation rate of Str. agalactiae was only $3.48 \%$. The prevalence of dominant mastitis pathogens differs considerably among countries. Even in the same country, it is always different among regions due to different management level and climate.

According to our results, mastitis pathogens were most prevalent in spring, which was in agreement with the study reported by Penev et al. (2014). This mainly due to the increased air temperature and high air humidity in spring after cold winter, which was beneficial for bacteria and accompanied by increased cases of IMI. In China, spring is a rainy season, which is a risk factor associated with CM (Oliveira et al., 2015). In addition, the weather in spring is highly variable, which may result in lower immunity of cattle. Opposite to results of Olde Riekerink et al. (2007b), who established the highest proportion of IMI during the winter, we found the lowest proportion of IMI in winter.

Taking each pathogen into consideration, environmental pathogens (E. coli and Str. uberis) were more common in summer. During the summer, the humidity and temperature are favorable for the development of coliform in the bedding. Costa et al. (1998) reported an increased occurrence of environmental IMI in Brazil mainly caused by Enterobacteriaceae and Str. uberis during hot and wet weather. Streptococcus uberis and $E$. coli were found to be more common during summer (Osterås et al., 2006; Koivula et al., 2007), which was in agreement with our findings. In addition, $S$. aureus was 
found more common in winter, which was in agreement with early research (Makovec and Ruegg, 2003).

In the present study, the influence of parity on IMI was not obvious, ranging from 61.80 to $68.46 \%$. Only Str. dysgalactiae exhibited a higher prevalence with increased parity, which is in agreement with an early study reported by Osterås et al. (2006). Laevens et al. (1997) were also unable to find the effect of parity for mastitis, but Sharma et al. (2013) revealed that the risk of an increase in SSC with higher parity.

A statistically significant higher incidence of IMI was found in the early lactation stage $(60.18 \%)$ than the late lactation stage $(50.95 \%)$. This was in line with many previous studies on cows (Nyman et al., 2007; Penev et al., 2014), and possibly due to impaired immune function in early lactation (Persson Waller et al., 2009). A negative correlation was found between LMT score (SCC) and the prevalence of E. coli. This was in agreement with Erskine et al. (1988), who found E. coli was more common in milk samples with low SCC (43.5\%) than high SCC samples (8.0\%). At cow level, there is a tendency to believe that low SCC fails to protect the udder from environmental pathogens (Burvenich et al., 2003), and cows may suffer even higher prevalence (Suriyasathaporn et al., 2000). Further research is required to better understand this phenomenon because SCC is not as simple as the number of cells present in milk; the type/sub-type of cell, its ability to function, and the speed of its recruitment to the udder will all almost certainly play a role (Bradley, 2002). Of note, mastitis pathogens were also isolated from healthy quarters (LMT score at -) as shown in Table 4. A similar result was obtained by Özenç et al. (2008) in Turkey. Hence, bacteriological examinations should be carried out together with LMT for mastitis diagnosis.

According to our results as shown in Table 5, a higher prevalence of IMI was found in the rear quarters than front quarters, but it was not statistically significant. However, E. coli exhibited a significant difference between quarters. A recent study (Dimitar and Metodija, 2012) reported that the rear quarters with IMI (49.39\%) in relation to the front one $(33.04 \%)$. During a 4 -yr retrospective study, Shpigel et al. (1998) also found the rear quarters had a higher incidence risk than the front quarters. The higher prevalence rate of IMI in the rear udder quarters may be due to their lower position compared with the front one, which make them more easily injured, and also greater milk yield produced by the rear quarters (Kocak, 2006). Streptococcus agalactiae was found mainly in front quarters $(P=0.05)$, and further research is needed to explain this phenomenon.

From the results presented in Table 6, increased DMY was a risk for IMI. This result was in agreement with Gröhn et al. (2004), who found IMI occurred more fre- quently in cows with higher milk production. Another report made in dairy goats indicated that the effect of IMI on milk yield was different for various pathogen groups (Koop et al., 2010). A negative relation between milk yield and IMI was reported by Gan et al. (2013), who also found the degree of IMI had a significant effect $(P<0.05)$ on SCC.

The prevalence of Str. agalactiae was higher $(P<$ 0.05) in cows with lower DMY, whereas E. coli and Str. uberis IMI were common in cows with higher milk production $(P<0.01)$. Most mastitis pathogens damage secretory tissue in the mammary gland, which is subsequently replaced by nonsecretory tissue (Zhao and Lacasse, 2008; Hertl et al., 2014). However, in moderate cases of E. coli IMI, the main changes were superficial and confined to the tissue, without serious involvement of the secretory tissue (Frost and Brooker, 1986).

The variation of clinical signs between udders infected with pathogens was obtained in the present study. Clinically, Bacillus species IMI is often presented as a hard quarter with white clots (Blowey and Edmondson, 2010). This was proved by the result of Pseudomonas aeruginosa in the present work. A survey with larger samples is needed in future work due to the limited samples used in this study. All of these findings may be helpful in identifying and treating bovine mastitis.

\section{CONCLUSIONS}

Various factors (season, parity, lactation, udder area, milk yield, and clinical symptoms) were proven to be associated with IMI. Contagious organisms were major pathogens for IMI in China, accounting for $85.87 \%$ of all isolates. Cows were more likely to be infected by environmental pathogens (E. coli or Str. uberis) in summer, in the rear quarters, and in cows with higher DMY or lower SCC. Streptococcus dysgalactiae exhibited a higher prevalence with increased parity. In addition, a variation of clinical signs between quarters with bacterial IMI was seen in this study, and mastitis pathogens were isolated from healthy quarters.

\section{ACKNOWLEDGMENTS}

This research is supported by The National Science \& Technology Pillar Program during the 12th Five-year Plan Period (2012BAD12B03), The Science \& Technology Pillar Program of Gansu (144NKCA240), Agricultural Science \& Technology Innovation Project of Gansu (GNCX-2013-59), and the Innovation Project of the Chinese Academy of Agricultural Sciences (research team of cow diseases). No conflict of interest exists in the submission of this manuscript. 


\section{REFERENCES}

Abdel-Rady, A., and M. Sayed. 2009. Epidemiological studies on subclinical mastitis in dairy cows in assiut governorate. Vet. World $2: 373-380$.

Blowey, R. W., and P. Edmondson. 2010. Mastitis Control in Dairy Herds. 2nd ed. Academic Press, Winslow, UK.

Boboš, S., M. Radinovic, B. Vidic, M. Pajic, V. Vidic, and A. Galfi. 2013. Mastitis therapy: Direct and indirect costs. Biotechnol Anim. Husb. 29:269-275.

Bradley, A. 2002. Bovine mastitis: An evolving disease. Vet. J. 164:116-128

Burvenich, C., V. Van Merris, J. Mehrzad, A. Diez-Fraile, and L. Duchateau. 2003. Severity of E. coli mastitis is mainly determined by cow factors. Vet. Res. 34:521-564.

Contreras, G. A., and J. M. Rodríguez. 2011. Mastitis: Comparative etiology and epidemiology. J. Mammary Gland Biol. Neoplasia 16:339-356.

Costa, E. O., A. R. Ribeiro, E. T. Watanabe, and P. A. Melville. 1998. Infectious bovine mastitis caused by environmental organisms. J. Vet. Med. 45:65-71.

Demme, B., and S. Abegaz. 2015. Isolation and identification of major bacterial pathogen from clinical mastitis cow raw milk in Addis Ababa, Ethiopia. Academic J. Anim. Dis. 4:44-51.

Dimitar, N., and T. Metodija. 2012. Udder quarter risk factors associated with prevalence of bovine clinical mastitis. Maced. Vet. Rev. $35: 55-64$

Erskine, R. J., R. J. Eberhart, L. J. Hutchinson, S. B. Spencer, and M. A. Campbell. 1988. Incidence and types of clinical mastitis in dairy herds with high and low somatic cell counts. J. Am. Vet. Med. Assoc. 192:761-765.

Ferguson, J. D., G. Azzaro, M. Gambina, and G. Licitra. 2007. Prevalence of mastitis pathogens in Ragusa, Sicily, from 2000 to 2006. J. Dairy Sci. 90:5798-5813.

Fox, L. K., and J. M. Gay. 1993. Contagious mastitis. Clin. North Am. Food Anim. Pract. 9:475-487.

Frost, A. J., and B. E. Brooker. 1986. Hyperacute Escherichia coli mastitis of cattle in the immediate post-partum period. Aust. Vet. J. $63: 327-331$

Gan, Z. H., Z. P. Yang, Y. L. Li, Y. J. Mao, X. H. Liu, and F. Chen. 2013. Relationship of bacterial infection with somatic cell count and milk composition in dairy cows with mastitis. Chinese J. Anim. Vet. Sci. 44:972-979. (in Chinese)

Gröhn, Y. T., D. J. Wilson, R. N. González, J. A. Hertl, H. Schulte, G. Bennett, and Y. H. Schukken. 2004. Effect of pathogen-specific clinical mastitis on milk yield in dairy cows. J. Dairy Sci. 87:3358-3374.

Hameed, K. G. A., G. Sender, and A. Korwin-kossakowska. 2007. Public health hazard due to mastitis in dairy cows. Anim. Sci. Pap. Rep. 25:73-85

Hertl, J. A., Y. Schukken, F. Welcome, L. Tauer, and Y. Gröhn. 2014 Pathogen-specific effects on milk yield in repeated clinical mastitis episodes in Holstein dairy cows. J. Dairy Sci. 97:1465-1480.

Holland, J. K., J. C. Hadrich, C. A. Wolf, and J. Lombard. 2015. Economics of measuring costs due to mastitis-related milk loss. 2015 AAEA \& WAEA Joint Annual Meeting, San Francisco, CA.

Kalmus, P., B. Aasmäe, A. Kärssin, O. Toomas, and K. Kalle. 2011. Udder pathogens and their resistance to antimicrobial agents in dairy cows in Estonia. Acta Vet. Scand. 53:4.

Keefe, G. P. 1997. Streptococcus Agalactiae mastitis: A review. Can. Vet. J. 38:429-437.

Kivaria, F. M. 2006. Epidemiological studies on bovine mastitis in smallholder dairy herds in the Dar Es Salaam region. MS Thesis. Utrecht Univ., Tanzania.

Kocak, O. 2006. Influence of mastitis on milk yield in Holstein cows. Acta Vet. (Brno) 75:507-513.

Koivula, M., A. Pitkälä, S. Pyörälä, and E. A. Mäntysaari. 2007. Distribution of bacteria and seasonal and regional effects in a new database for mastitis pathogens in Finland. Acta Agric. Scand. Anim. Sci. 57:89-96.
Koop, G., T. V. Werven, H. J. Schuiling, and M. Nielen. 2010. The effect of subclinical mastitis on milk yield in dairy goats. J. Dairy Sci. 93:5809-5817.

Kvapilik, J., O. Hanus, J. Syrucek, M. Vyletelova-Klimesova, and P. Roubal. 2014. The economic importance of the losses of cow milk due to mastitis-A meta-analysis. Bulgarian J. Agric. Sci. 20:14831497.

Laevens, H., H. Deluyker, Y. H. Schukken, L. D. Meulemeester, R. Vandermeersch, E. D. Muêlenaere, and A. D. Kruif. 1997. Influence of parity and stage of lactation on the somatic cell count in bacteriologically negative dairy cows. J. Dairy Sci. 80:3219-3226.

Leblanc, S. J., K. Lissemore, D. Kelton, T. Duffield, and K. Leslie. 2006. Major advances in disease prevention in dairy cattle. J. Dairy Sci. 89:1267-1279.

Leelahapongsathon, K., Y. Schukken, and W. Suriyasathaporn. 2014 Quarter, cow, and farm risk factors for intramammary infections with major pathogens relative to minor pathogens in Thai dairy cows. Trop. Anim. Health Prod. 46:1067-1078.

Li, S. L., Z. J. Cao, Y. M. Liu, J. M. Xia, Y. J. Wang, D. Q. Yang, K. Yao, W. Du, P. N. Zhai, and X. T. Kang. 2015. Review and prospect of China dairy industry in 2014. Chinese J. Anim. Sci. 51:22-28. (in Chinese).

Liu, X., X. Wang, and K. Zhan. 1983. A method for the diagnosis of subclinical bovine mastitis in the field-The Lanzhou mastitis test. Scientia Agricultura Sinica 2:87-92. (in Chinese).

Makovec, J. A., and P. L. Ruegg. 2003. Results of milk samples submitted for microbiological examination in Wisconsin from 1994 to 2001. J. Dairy Sci. 86:3466-3472.

Memon, J. 2013. Prevalence of bovine mastitis and molecular epidemiology of major mastitis pathogen in Eastern China. MS Thesis. Nanjing Agricultural University, China.

Mweu, M. M., N. Toft, J. Katholm, and S. S. Nielsena. 2012. Evaluation of two herd-level diagnostic tests for Streptococcus agalactiae, using a latent class approach. Vet. Microbiol. 159:181-186.

Nyman, A. K., T. Ekman, U. Emanuelson, A. H. Gustafsson, K. Holtenius, K. P. Waller, and C. H. Sandgren. 2007. Risk factors associated with the incidence of veterinary-treated clinical mastitis in Swedish dairy herds with a high milk yield and a low prevalence of subclinical mastitis. Prev. Vet. Med. 78:142-160.

Olde Riekerink, R. G. M., H. W. Barkema, and H. Stryhn. 2007a. The effect of season on somatic cell count and the incidence of clinical mastitis. J. Dairy Sci. 90:1704-1715.

Olde Riekerink, R. G. M., H. Barkema, D. Poole, D. Kelton, and D. Scholl. 2007b. Risk factors for incidence rate of clinical mastitis in a nationwide study on Canadian dairy farms. Pages 204-205 in Proc 46th Annu. Mtg. Natl. Mast. Council.

Oliveira, C. S. F., H. Hogeveen, A. M. Botelho, P. V. Maiad, S. G Coelhob, and J. P. A. Haddada. 2015. Cow-specific risk factors for clinical mastitis in Brazilian dairy cattle. Prev. Vet. Med. 121:297305.

Osterås, O., L. Sølverød, and O. Reksen. 2006. Milk culture results in a large Norwegian survey_Effects of season, parity, days in milk, resistance, and clustering. J. Dairy Sci. 89:1010-1023.

Özenc, E., M. R. Vural, E. Seker, and M. Uçar. 2008. An evaluation of subclinical mastitis during lactation in Anatolian buffaloes. Turk. J. Vet. Anim. Sci. 32:359-368.

Penev, T., Z. Gergovska, I. Marinov, V. Kirov, K. Stankov, Y. Mitev, and C. Miteva. 2014. Effect of season, lactation period and number of lactation on mastitis incidence and milk yields in dairy cows. Agric. Sci. Technol. 6:231-238.

Persson Waller, K., B. Bengtsson, A. Lindberg, A. Nyman, and H. E. Unnerstad. 2009. Incidence of mastitis and bacterial findings at clinical mastitis in Swedish primiparous cows-Influence of breed and stage of lactation. Vet. Microbiol. 134:89-94.

Piessens, V., E. V. Coillie, B. Verbist, K. Supré, G. Braem, A. V. Nuffel, L. D. Vuyst, M. Heyndrickx, and S. D. Vliegher. 2011. Distribution of coagulase-negative Staphylococcus species from milk and environment of dairy cows differs between herds. J. Dairy Sci. 94:2933-2944. 
Rashad, A., W. Jianfang, G. Jian, A. Tariq, C. Wei, S. I. Ottó, C. B. Árpád, and H. Bo. 2016. Properties and antimicrobial susceptibility of Trueperella pyogenes isolated from bovine mastitis cases in China. Acta Vet. Hung. 64:1-12.

Sharma, N., T. Y. Kang, S. Lee, J. N. Kim, C. H. Hur, J. C. Ha, V. Vohra, and D. K. Jeong. 2013. Status of bovine mastitis and associated risk factors in subtropical Jeju Island, South Korea. Trop. Anim. Health Prod. 45:1829-1832.

Shpigel, N. Y., M. Winkler, G. Ziv, and A. Saran. 1998. Clinical, bacteriological and epidemiological aspects of clinical mastitis in Israeli dairy herds. Prev. Vet. Med. 35:1-9.

Song, Y. P., and L. G. Yang. 2010. Research progress of mastitis control in dairy cow. China Dairy Cattle 12:48-53. (in Chinese).

Suriyasathaporn, W., Y. Schukken, M. Nielen, and A. Brand. 2000. Low somatic cell count: A risk factor for subsequent clinical mastitis in a dairy herd. J. Dairy Sci. 83:1248-1255. van den Borne, B. H. P., G. van Schaik, T. J. Lam, and M. Nielen. 2010. Variation in herd level mastitis indicators between primiand multiparae in Dutch dairy herds. Prev. Vet. Med. 96:49-55.

Xu, D., Z. Hou, and W. Fan. 2005. Epidemiologic survey and isolation and identification of pathogenic bacteria of bovine subclinical mastitis. Liaoning J. Anim. Husbandry Vet. Med. 2005:40-41.

Yuan, Y. L., Y. X. Zhang, Y. Zh. Hou, Y. Y. Yang, and H. S. Li. 1991. Procedure for isolation and identification of bacteria in milk with bovine mastitis. Chin. J. Vet. Sci. Technol. 21:7-10.

Zadoks, R. N., and J. L. Fitzpatrick. 2009. Changing trends in mastitis. Ir. Vet. J. 62:S59-S70.

Zhao, X., and P. Lacasse. 2008. Mammary tissue damage during bovine mastitis: Causes and control. J. Anim. Sci. 86:57-65. 